\title{
Peningkatan Penguasaan Konsep Siswa SMA tentang Hukum Gravitasi Newton melalui Modeling Instruction
}

\author{
Zulfi Farida Alfianti ${ }^{1}$, Sutopo ${ }^{1}$, Sunaryono ${ }^{1}$ \\ ${ }^{1}$ Pendidikan Fisika-Universitas Negeri Malang
}

\begin{tabular}{l} 
INFO ARTIKEL \\
\hline Riwayat Artikel: \\
Diterima: 09-05-2019 \\
Disetujui: $12-12-2019$ \\
\hline
\end{tabular}

Kata kunci:

mastery of concepts; modeling instruction; Newton's law of gravity; penguasaan konsep; modeling instruction; hukum gravitasi newton

\author{
Alamat Korespondensi: \\ Zulfi Farida Alfianti \\ Pendidikan Fisika \\ Universitas Negeri Malang \\ Jalan Semarang 5 Malang \\ E-mail: zulfifarida@yahoo.co.id
}

\begin{abstract}
The purpose of this study was to determine the increase in mastery of student concepts in Newton's Gravity Law material through Modeling Instruction. This research model uses a Mixed Method. The subjects of this research were 60 students in one of the schools in Batu city in grade X Science. Data obtained through statistical analysis of the value of the pretest and posttest. The results of the study show that teaching using Modeling Instruction can increase mastery of concepts by 0.65 with the medium category.
\end{abstract}

ABSTRAK

\begin{abstract}
Abstrak: Tujuan penelitian ini adalah untuk mengetahui peningkatan penguasaan konsep siswa pada materi Hukum Gravitasi Newton melalui Modeling Instruction. Model penelitian ini menggunakan Mixed Method. Subjek penelitian ini adalah siswa di salah satu sekolah di kota Batu kelas X IPA sebanyak 60 siswa. Data diperoleh melalui analisis statistik nilai pretest dan postest. Hasil penelitian menunjukkan bahwa pengajaran menggunakan Modeling Instruction dapat meningkatkan penguasaan konsep sebesar 0,65 dengan kategori sedang.
\end{abstract}

Tujuan penting pembelajaran fisika yaitu mengantarkan siswa memahami konsep secara mendalam sehingga siswa mampu menerapkannya untuk memecahkan masalah fisika. Pentingnya memahami konsep pada materi fisika dibuktikan dengan banyaknya penelitian terkait pendidikan fisika sejak tahun 1970-an (Docktor \& Mestre, 2014). Hasil penelitian yang telah dilakukan menunjukkan banyak siswa yang mengalami kesulitan dalam memahami konsep dan bertentangan dengan sudut pandang ahli fisika (Halloun \& Hestenes, 1985). Salah satu materi fisika yang dianggap sulit dan abstrak adalah materi Hukum Gravitasi Newton. Namun, penelitian tentang Hukum Gravitasi Newton masih jarang dilakukan sehingga perlu diakukan penelitian untuk mengetahui penguasaan konsep siswa terhadap materi Hukum Gravitasi Newton.

Banyak cara telah diterapkan untuk meningkatkan kualitas pendidikan. Salah satu cara yang digunakan yaitu keterbaruan pengajaran dalam kurikulum yang bertujuan untuk mengeksplorasi keterampilan para siswa (González dkk., 2004; Tirado dkk., 2014). Siswa mengonstruksi keterampilan dan pengetahuan dengan bantuan Guru (McBride dkk., 2010). Salah satu pengajaran yang dapat meningkatkan keterampilan dan mengonstruksi yaitu Modeling Instruction (Jackson dkk., 2008). Pengajaran Modeling melibatkan siswa lebih aktif dalam pembelajaran sehingga pengajaran yang mulanya berpusat pada guru beralih menjadi berpusat kepada siswa. Pengajaran melalui Modeling Instruction dilaksanakan melalui dua tahap, yaitu model Development dan model Deployment. Pada tahap Development siswa membangun model melalui kegiatan praktikum dan diskusi, selanjutnya pada tahap Deployment siswa menerapkan model yang telah diperoleh untuk menyelesaikan masalah fisika.

Pengajaran melalui Modeling mampu meningkatkan penguasaan konsep siswa dibandingkan dengan pengajaran non Modeling (Malone, 2008; Wells dkk., 1995). Perubahan pemahaman konsep siswa mengalami perubahan menjadi lebih baik ketika diterapkan pembelajaran Modeling (Brewe dkk., 2010). Menurut penelitian lain menunjukkan bahwa pengajaran Modeling dapat meningkatkan penguasaan konsep siswa pada materi Momentum dan Implus (Saifullah dkk., 2017). Oleh karena itu, teknik pengajaran dengan Modeling cocok apabila diterapkan pada materi fisika, dimana kualitas pendidikan masih rendah, tetapi perubahan kurikulum terus berkembang (González dkk., 2004). Namun, pengajaran Modeling pada materi Hukum Gravitasi Newton masih jarang dilakukan, sehingga perlu dilakukan penelitian untuk mengetahui peningkatan penguasaan konsep siswa pada materi Hukum Gravitasi Newton melalui Modeling Instruction. 


\section{METODE}

Tujuan penelitian ini yaitu untuk mengetahui peningkatan konsep siswa pada materi Hukum Gravitasi Newton melalui pembelajaran Modeling. Model penelitian ini menggunakan pendekatan campuran (Mixed Method) dengan analisis data secara kuantitatif dan kualitatif. Subjek penelitian ini adalah siswa kelas X salah satu sekolah di kota Batu sebanyak 60 siswa yang sedang menempuh materi Hukum Gravitasi Newton. Siswa diberikan tes penguasaan konsep berupa soal pilihan ganda. Soal pretest dikerjakan oleh siswa sebelum memperoleh pengajaran dan soal postest dikerjakan setelah mendapat pengajaran. Soal pretest dan postest yang diujikan kepada siswa merupakan soal yang sama. Selain memberikan jawaban pada soal, siswa juga diminta untuk memberikan alasan secara ilmiah pada setiap butir soal. Butir soal yang diujikan memiliki indikator untuk mencapai kompetensi. Sebaran butir soal pada setiap indikator ditampilkan pada tabel 1.

Tahap pengajaran yang dilakukan melalui Modeling Instruction dilaksanakan melalui dua tahapan, yaitu tahap Development dan tahap Deployment (Jackson dkk., 2008). Tahap Development, dimana siswa memperoleh data melalui praktikum melalui aplikasi PhET yang digunakan untuk membuat model tentang fenomena fisis. Data yang diperoleh melalui praktikum melalui PhET selanjutnya digunakan untuk menghasilkan hubungan antara gaya gravitasi dan massa benda maupun hubungan gaya gravitasi dengan jarak antar kedua pusat benda. Representasi model yang dihasilkan selanjutnya ditampilkan oleh siswa melalui diskusi kelas dalam bentuk kelompok. Penjelasan lebih lanjut dan penguatan diberikan oleh guru setelah setiap kelompok menampilkan hasil diskusi masing-masing. tahap Deployment, dimana siswa memperkuat konsep dan model yang didapat melalui praktikum. Pada tahap Deployment siswa menggunakan model yang telah dihasilkan untuk memecahkan masalah fisika. Dalam tahap ini siswa diberikan soal berupa penerapan dan kuis sehingga pada tahap ini siswa dapat mengaplikasikan konsep yang telah didapatkan pada tahap Development.

Tabel 1. Butir Soal pada Indikator

\begin{tabular}{cllc}
\hline No & & Indikator & Butir Soal \\
\hline 1 & Menganalisis sifat-sifat gaya gravitasi & $1,2,4$ \\
2 & Mengidentifikasi arah gaya gravitasi dan besar gaya gravitasi pada benda yang saling berinteraksi & $3,5,8,11$ \\
3 & Menganalisis hubungan hukum Gravitasi Newton dengan Hukum Newton & $6,7,9,10$ \\
\hline
\end{tabular}

Analisis data secara kualitatif dilakukan melalui penilaian dari skor pretest dan postest. Skor yang dihasilkan kemudian dikelompokkan berdasarkan jawaban benar dan salah yang nantinya dianalisis menggunakan $N$-Gain untuk mengetahui peningkatan penguasaan konsep siswa pada (Hake, 1998). Analisis data secara kuantitatif dilakukan dengan melihat perubahan pemikiran siswa dari pretest ke postest (crostabulation) melalui alasan yang dipaparkan.

\section{HASIL}

Kenaikan jumlah jawaban benar oleh siswa ditunjukkan oleh tabel 2. Data dikelompokkan pada jawaban salah dan benar pada pretest dan postest. Pengelompokkan didasarkan pada persentase jumlah siswa yang menjawab benar dan salah.

Tabel 2. Kenaikan Jumlah Jawaban Benar

\begin{tabular}{|c|c|c|c|c|}
\hline \multirow[t]{2}{*}{ No } & \multirow[t]{2}{*}{ Indikator } & \multicolumn{2}{|c|}{ Proporsisi Jawaban Benar (\%) } & \multirow{2}{*}{$\begin{array}{l}\text { Perubahan } \\
(\%)\end{array}$} \\
\hline & & Pretest & Posttest & \\
\hline 1 & Menganalisis sifat-sifat gaya gravitasi & 17,2 & 48,3 & 31,1 \\
\hline 2 & $\begin{array}{l}\text { Mengidentifikasi arah gaya gravitasi dan besar gaya gravitasi pada benda yang } \\
\text { saling berinteraksi }\end{array}$ & 19,2 & 51,7 & 32,5 \\
\hline 3 & Menganalisis hubungan hukum Gravitasi Newton dengan Hukum Newton & 10,4 & 74,6 & 64,2 \\
\hline
\end{tabular}

Berdasarkan tabel 2 dapat dilihat bahwa terjadi peningkatan pada setiap indikator soal. Jumlah siswa yang menjawab benar mengalami peningkatan setelah mendapat pembelajaran dengan Modeling. Selanjutnya, dilakukan analisis deskriptif untuk mengetahui besar peningkatan penguasaan konsep siswa melalui analisis $N$-Gain. Hasil analisis statistik deskriptif ditampilkan pada tabel 3 .

Tabel 3. Statistik Deskriptif Pretest dan Postes Siswa

\begin{tabular}{lcc}
\hline \multicolumn{1}{c}{ Unsur Statistik } & Pretest & Posttest \\
\hline Mean & 106 & 390 \\
Rata-Rata & 1,8 & 6,5 \\
Maximum Skor & 5 & 9 \\
Minimum Skor & 0 & 3 \\
Standar Deviasi & 1,00 & 2,15 \\
Skewness & 0,49 & $-0,29$ \\
\hline
\end{tabular}


Penilaian didasarkan pada jawaban benar dan salah. Skor 1 untuk jawaban benar dan skor 0 untuk jawaban salah. Berdasarkan tabel 3 dapat dilihat bahwa terjadi peningkatan dari pretest ke postest. Penguasaan konsep yang meningkat dapat dilihat melalui nilai $N$-gain. Perhitungan nilai $N$-gain yang dihasilkan masuk dalam kategori sedang, yaitu 0,65 (Hake, 1998). Penentuan distribusi data dilakukan dengan uji skewness. Nilai skewness yang dihasilkan pada data pretes dan posttest terletak pada interval -1 sampai dengan +1 , artinya data terdistribusi normal. Efektivitas model pembelajaran yang diterapkan dianalisis menggunakan $d$-effect size. Hasil yang diperoleh dari perhitungan $d$-effect size sebesar 2,5 dengan kategori sangat besar (Morgan dkk., 2004), artinya model pembelajaran yang diterapkan dapat meningkatkan penguasaan konsep siswa terhadap materi Hukum Gravitasi Newton.

\section{PEMBAHASAN}

Berdasarkan tabel 2 dapat dilihat bahwa terjadi peningkatan pemahaman konsep pada setiap indikator. Perhitungan $d$ effect size menunjukkan bahwa pemahaman konsep siswa mengalami peningkatan dan masuk dalam kategori sangat besar dan hasil hasil rata-rata $\mathrm{N}$-gain masuk dalam kategori sedang. Model pengajaran melalui Modeling Instruction cocok diterapkan pada materi Hukum Gravitasi Newton.

Indikator soal memuat beberapa butir soal penguasaan konsep. Berikut disajikan butir soal yang mengalami peningkatan sangat tinggi beserta alasan siswa, dimana siswa dapat menjawab butir soal dengan benar setelah mendapat pengajaran. Kemampuan yang meningkat paling tinggi terjadi pada salah satu butir pada indikator menganalisis sifat-sifat gaya gravitasi. Siswa yang semula kurang paham dengan konsep gaya gravitasi, paham konsep setelah mendapat pengajaran. Perubahan jawaban siswa ditampilkan beserta alasan yang dikemukakan oleh siswa. Berikut salah satu pembahasan butir soal pada salah satu indikator.

\section{Menentukan Besar Gaya Gravitasi}

Butir soal memuat besarnya gaya gravitasi yang dikerjakan antara planet dengan bulan 2. Detail berdasarkan soal ditampilkan pada gambar 1 .

Sebuah planet memiliki dua buah bulan dengan massa yang sama. Bulan 1 memiliki orbit lingkaran

dengan jari-jari r. Bulan 2 memiliki orbit lingkaran dengan jari-jari 2r. Besarnya gaya gravitasi yang

dikerjakan antara planet dan bulan 2 adalah...

A. 4 kali dari gaya gravitasi yang dikerjakan planet pada Bulan 1

B. 2 kali dari gaya gravitasi yang dikerjakan planet pada Bulan 1

C. Sama dengan gaya gravitasi yang dikerjakan planet pada Bulan 1

D. $\frac{1}{2}$ kali dari gaya gravitasi yang dikerjakan planet pada Bulan 1

E. $\frac{1}{4}$ kali dari gaya gravitasi yang dikerjakan planet pada Bulan 1

\section{Gambar 1. Butir Soal Hubungan Hukum Gravitasi dengan Hukum Newton}

Distribusi jawaban siswa pada butir soal nomor 3 saat pretest dan postest ditampilkan pada tabel 4. Distribusi jawaban dikelompokkan berdasarkan jawaban benar pada saat pretest dan postest.

Tabel 4. Sebaran Jawaban Siswa pada Butir Soal Nomor 3

\begin{tabular}{ccccccc}
\hline & \multicolumn{7}{c}{ Posttest } \\
\hline Pretest & A & B & D & E* $^{*}$ & Total Pretest \\
& A & 0 & 0 & 1 & 0 & 1 \\
& B & 1 & 1 & 21 & 19 & 42 \\
& C & 0 & 0 & 0 & 2 & 2 \\
& D & 1 & 0 & 3 & 7 & 11 \\
& NA & 0 & 0 & 0 & 4 & 4 \\
\hline \multicolumn{2}{l}{ Total Postest } & $\mathbf{2}$ & $\mathbf{1}$ & $\mathbf{2 5}$ & $\mathbf{3 2}$ & $\mathbf{6 0}$ \\
\hline
\end{tabular}

Setelah melalui proses pengajaran, siswa yang menjawab benar jumlahnya meningkat. Pada saat pretest, tidak ada satu pun siswa yang menjawab benar, satu orang siswa memilih jawaban A, 42 orang siswa memilih jawaban B, 2 siswa memilih C, 11 siswa menjawab D, dan sisanya empat siswa memilih tidak memberikan jawaban (No Answer). Sebagian besar siswa memilih jawaban B dengan memberikan alasan "karena jari-jari bulan ke-2 lebih besar dari jari-jari bulan ke-l". Siswa yang 
memilih jawaban A memberikan alasan bahwa "jari-jari bulan $2=2 r^{2}$, sehingga bulan 2 menjadi 4 kali lipat dari bulan 1 ". Siswa yang memilih jawaban C tidak memberikan alasan. Siswa yang memilih jawaban D memberikan alasan yang kurang jelas, yaitu" karena jari-jari orbit lingkaran $1 r=1 / 2$ ".

Berdasarkan alasan yang dikemukakan oleh siswa yang memilih jawaban A dan B menganggap apabila jari-jari orbit lingkaran semakin besar maka besar gaya gravitasi yang dihasilkan juga semakin besar. Namun, siswa yang memilih jawaban D memberikan alasan yang kurang jelas bahkan ada yang tidak memberikan alasan. Pada saat postest terjadi perubahan jawaban siswa. Jumlah siswa yang memilih jawaban benar meningkat menjadi 32 siswa, sedangkan 25 siswa memilih jawaban D. Namun, dari 32 siswa yang memilih jawaban E, 5 di antaranya tidak memberikan alasan dan 27 siswa sudah memberikan alasan yang benar. Siswa yang memilih jawaban D saat postest meningkat menjadi 25 siswa yang mulanya saat pretest hanya 11 siswa. Siswa yang memilih jawaban D memberikan alasan "Bulan 1 memiliki jari-jari orbit $r$, sedangkan bulan 2 memiliki jari-jari orbit $2 r$ sehingga gaya gravitasinya menjadi $1 / 2$ ”. Berdasarkan alasan tersebut dapat dikatakan bahwa siswa yang memilih jawaban D masih belum paham dengan sifat gaya gravitasi bahwa gaya gravitasi berbanding terbalik dengan kuadrat jarak antar kedua benda.

Berdasarkan hasil yang telah diperoleh siswa, pembelajaran Modeling Instruction sangat berpengaruh dalam meningkatkan penguasaan konsep siswa pada materi Hukum Gravitasi Newton. langkah awal yang diterapkan pada siswa yaitu praktikum melalui aplikasi PhET untuk memperoleh data yang nantinya digunakan untuk menemukan hubungan antara Gaya Gravitasi dengan jarak benda. Selanjutnya, berdasarkan data yang diperoleh siswa menentukan hubungan gaya gravitasi dengan jarak benda. Berdasarkan data yang telah diperoleh, siswa dapat menentukan hubungan yang dicari sehingga dapat menyelesaikan soal yang ditanyakan.

\section{SIMPULAN}

Pengajaran melalui Modeling dapat meningkatkan pemahaman konsep siswa pada materi Hukum Gravitasi Newton dengan $d$-effect size sebesar 2,5 pada kategori sangat besar dan $N$-gain sebesar 0,65 pada kategori sedang. Model pengajaran melalui Modeling memiliki pengaruh besar dalam meningkatkan penguasaan konsep siswa dan mengarahkan pemikiran pada konsep yang benar. Pemikiran siswa yang masih belum benar yaitu memahami salah satu sifat gaya gravitasi bahwa gaya gravitasi berbanding terbalik dengan kuadrat jarak antar kedua benda.

Pembelajaran Modeling Instruction cocok diterapkan pada materi fisika. Diharapkan kepada guru untuk menerapkan model pembelajaran Modeling Instruction pada materi fisika yang lainnya. Kepada peneliti selanjutnya untuk menambahkan pendekatan pada pembelajaran Modeling sehingga siswa lebih maksimal dalam menggunakan konsep fisikanya.

\section{DAFTAR RUJUKAN}

Brewe, E., Sawtelle, V., Kramer, L. H., O’Brien, G. E., Rodriguez, I., \& Pamelá, P. (2010). Toward Equity Through Participation in Modeling Instruction in Introductory University Physics. Physical Review Special Topics-Physics Education Research, 6(1), 010106.

Docktor, J. L., \& Mestre, J. P. (2014). Synthesis of Discipline-Based Education Research in Physics. Physical Review Special Topics-Physics Education Research, 10(2), 020119.

González, J., Wagenaar, R., \& Beneitone, P. (2004). Tuning-América Latina: un proyecto de las universidades. Revista iberoamericana de educación, 35(1), 151-164.

Hake, R. R. (1998). Interactive-Engagement Versus Traditional Methods: A Six-Thousand-Student Survey of Mechanics Test Data for Introductory Physics Courses. American journal of Physics, 66(1), 64-74.

Halloun, I. A., \& Hestenes, D. (1985). The Initial Knowledge State of College Physics Students. American Journal of Physics, 53(11), 1043-1055.

Jackson, J., Dukerich, L., \& Hestenes, D. (2008). Modeling Instruction: An Effective Model for Science Education. 17(1), 9.

Malone, K. L. (2008). Correlations among Knowledge Structures, Force Concept Inventory, and Problem-Solving Behaviors. Physical Review Special Topics-Physics Education Research, 4(2), 020107.

McBride, D. L., Zollman, D., \& Rebello, N. S. (2010). Method for Analyzing Students' Utilization of Prior Physics Learning in New Contexts. Physical Review Special Topics-Physics Education Research, 6(2), 020101.

Morgan, G. A., Leech, N. L., Gloeckner, G. W., \& Barrett, K. C. (2004). SPSS for Introductory Statistics: Use and Interpretation. Psychology Press.

Saifullah, A. M., Sutopo, S., \& Wisodo, H. (2017). Senior High School Students' Difficulties in Solving Impulse and Momentum Problems. Jurnal Pendidikan IPA Indonesia, 6(1), 1-10.

Tirado, L. J., Estrada, J., Ortiz, R., Solano, H., Alfonso, D., Restrepo, G., ... Ortiz, D. (2014). Competencias Profesionales: una estrategia para el desempeño exitoso de los ingenieros industriales. Revista Facultad de Ingeniería, (40), $123-139$.

Wells, M., Hestenes, D., \& Swackhamer, G. (1995). A Modeling Method for High School Physics Instruction. American Journal of Physics, 63(7), 606-619. 